\title{
The role of oxidative stress and inflammatory response in the pathogenesis of mastitis in dairy cows
}

\author{
doi: $10.15567 /$ mljekarstvo.2017.0201 \\ Romana Turk ${ }^{1}$, Matea Koledić ${ }^{1}$, Nino Maćešić ${ }^{1}$, Miroslav Benić ${ }^{2}$, Vesna Dobranić ${ }^{1}$, \\ Dražen Đuričić ${ }^{3}$ Luka Cvetnić ${ }^{2}$ and Marko Samardžija ${ }^{1 *}$ \\ ${ }^{1}$ University of Zagreb, Faculty of Veterinary Medicine, Heinzelova 55, 10000 Zagreb, Croatia \\ ${ }^{2}$ Croatian Veterinary Institute, Savska cesta 143, 10000 Zagreb, Croatia \\ ${ }^{3}$ Veterinary Practice Đurđevac, Malinov trg 7, 48350 Đurđevac, Croatia
}

Received - Prispjelo: 25.11.2016. Abstract Accepted - Prihvaćeno: 06.04.2017.

Mastitis is one of the most frequent diseases of dairy cows throughout the world, therefore it causes the greatest economic losses in dairy cattle industry. These losses are reflected through: reduced milk production, increased costs of medication and the other animal health services, reduced fertility, early culling of animals and the value of discarded milk. Mastitis is also important from the aspects of public health, milk processing and animal welfare. In the pathogenesis of mastitis the key role plays the innate immune response which is the first line of defence against the pathogen invasion of the udder. The innate immune response generates an inflammatory reaction which is the elementary response of an organism to the tissue trauma induced by any physical, chemical or biological causative agent, but primarily it is the protective mechanism of a vital significance which includes increased phagocytic activity, secretion of antimicrobial substances, fibrosis as well as the alterations in tissue structure of affected organ or body cavity. The release of a number of inflammatory mediators as well as reactive oxygen species (ROS) is an important part of inflammatory response. In dairy cows, the metabolic challenge that occurred during the transition from dry period to early lactation may additionally increase the release of ROS which may contribute to development of oxidative stress and inflammatory response. Oxidative stress is defined as a shift in the balance from cellular oxidation-reduction reactions towards oxidation, i.e. to the state of excessive release of oxidants when their removal by antioxidants is impaired and even insufficient. During peripartum period antioxidantive status of dairy cows is seriously impaired and consequently both the oxidative stress and inflammatory response may present the predisposing factors to their higher susceptibility to intramammary infections (IMI) and mastitis. This association between oxidative stress and inflammation during IMI and mastitis indicates their role in the pathogenesis of mastitis. Thus, a better understanding of such a synergism could contribute to development of new approaches to prevention and therapy of IMI and mastitis.

Key words: oxidative stress, inflammatory response, mastitis, peripartum, cow

\section{Introduction}

Bovine mastitis is one of the most frequent diseases of dairy cows throughout the world, therefore it causes the greatest economic losses in dairy cattle industry. These losses are reflected through: reduced milk production, increased costs of medication and the other animal health services, reduced fertility, early culling of animals and the value of discarded milk (Cvetnić et al., 2016). Mastitis is also important in terms of public health, milk processing and animal welfare. The interactions between immune system of cow and causative agents of mastitis result 
in damages of the secretory part of the udder and when the latter is substituted with fibrotic tissue the process becomes irreversible, and the affected quarter or the whole udder is no longer functionally capable for milk production and secretion (Djuricic et al., 2014).

During the last few decades in veterinary medicine there has been increased interest in interactions between stress and immunity, particularly in farm animals (Bassols et al., 2014; Turk at al., 2015). In order to survive rapid and significant changes occurring due to the influence of external and internal stimuli, including a vast variety of environmental stressors, animals respond by the complex mechanisms to maintain biological balance, i.e. homeostasis. Such balance could be permanently compromised and, thus, evolved homeostatic physiological processes comprising numerous molecular and cellular defence mechanisms (Valpotić, 2002). More recently, the investigations were focused on oxidative stress as well as on antioxidants which may to certain extent diminish or totally reduce cell damages caused by oxidative stress (Turk at al., 2013 and 2016; Folnožić et al., 2015). Oxidative stress is defined as a shift in the balance between cellular oxidation-reduction reactions towards increasing oxidation and to the state of excessive release of reactive oxygen species (ROS), when their removal by antioxidants is impaired and even insufficient (Kumar et al., 2011).

Excessive release of ROS is detrimental for molecular structure of cell membranes resulting in functional alterations of affected cells and thus malfunctioning of tissues and organs. Oxidative stress is associated with many diseases including sepsis, enteritis, pneumonia and arthritis in animals of veterinary importance. In dairy cows, it may cause mastitis and reproductive disorders (Turk at al., 2011 and 2012) which may directly influence their productivity by reducing milk production (Lykkesfeldt and Svendsen, 2007). Disorders in dairy cows such as udder oedema, retained placenta and mastitis may reduce milk production and its economic value and may unfavourably influence productivity cycle of dairy cattle.

Taking that into consideration, the aim of this review was to compile and summarize recent knowledge regarding oxidative stress in ruminants, particularly its pathophysiological role in the pathogenesis of mastitis in dairy cows as well as to review scientifically documented data on harmful influence of oxidative stress on health and productivity of dairy cows.

\section{Mastitis}

One of the most frequent udder diseases in dairy cows could be ascribed to the inflammation of the mammary gland (mastitis) caused by numerous pathogens. The importance of mastitis is emphasised by the fact that it produces huge losses in cattle industry (Salman, 2009; Maćešić et al., 2016). Also, its importance is significant from the aspect of public health, milk processing and animal welfare (Bačić, 2009). The mastitis incidence is influenced by diverse factors including environmental conditions, host resistance and inappropriate farm management (Gračner et al., 2006). Since mastitis is caused by different microorganisms, the prevention, treatment and control of the disease are hardly feasible (Russell, 2011). Upon inflammation of mammary gland of any etiology it is easy to observe organoleptic, chemical and bacteriological changes in milk along with the pathological changes in udder parenchyma (Radostitis et al., 2000). Significant factors contributing to development of this disease are deviation of basic animal sanitary and technical measures as well as non-observance of basic postulates for hygienic milking and appropriate technical service of milking devices (Benić, 2011). Mastitis is caused by a wide spectrum of Gram negative and Gram positive bacteria and fungi and, thus it is difficult to expect complete cure of diseased animals (Deb et al., 2013). In addition, mastitis is considered as a significant public health problem due to the fact that some causative agents are zoonotic such as Staphylococcus aureus, Salmonella spp., Listeria spp. or Escherichia coli. Mastitis caused by S. aureus and E. coli are relatively frequent, while those caused by Salmonella and Listeria spp. are extremely rare.

Economic losses due to mastitis are reflected through: reduced milk production, increased costs of medication and the other animal health services, reduced fertility, early culling of animals and the value of discarded milk. Mastitis is also important from the aspects of public health, milk processing and animal welfare. All these losses directly impact the profit of the farm. 


\section{Composition of mastitic milk}

During mastitis permeability of blood vessels is increased and thus different components of blood may pass directly from blood vessels into milk. Consequently, various enzymes may change milk composition by inducing degradation of casein and milk fats (Roncada at al., 2012). Chemical composition of milk varies upon the health status of the mammary gland. Compared with the healthy gland, protein components of milk from inflamed gland are changed rapidly. Proportion of casein drops while the proportions of other non-desirable protein components such as serum albumin, immunoglobulins and transferrin are higher due to the elevated permeability of capillaries. Proteolytic activity of milk from inflamed gland is higher which has negative influence on the quality of dairy products (Barbano et al., 1987). Total protein content is not significantly changed due to mastitis but the quality of milk and milk products is reduced. The somatic cell count (SCC) is not necessarily extremely high in milk of lower quality. However, the contamination of milk with antimicrobials is higher in farms with high SCC in comparison to the farms which successfully perform preventive and control measures of mastitis (Dobranić et al., 2007; Bačić, 2009). Several factors may induce elevation of somatic cell count in milk. However, bacterial infections of mammary gland are the most important one. Soon following the infection, bacteria start multiplying in tissue and producing toxins and enzymes which stimulate releasing of mediators of inflammation. Mediators attract the immune cells such as leukocytes and macrophages toward the infected tissue. Mass of mainly polymorphonuclear granulocytes pass between secretory cells ending in the alveolar lumen and finally in mammary gland secretion. Intensity of inflammation and consequently the number of attracted cells depend on type of pathogen, lactation phase, animal immune status, genetics and nutrition status (Mattila, 1986). Clinically, mastitis could be differentiated into subclinical or clinical form (Bačić, 2009). Subclinical mastitis is characterized by a mild inflammation of the mammary gland which could not be diagnosed following external inspection of the udder due to hidden clinical signs. There are no visible change neither of the udder nor in milk during subclinical form of the disease. Due to huge economic losses subclinical inflammation of the mammary gland is considered as the most significant disease of dairy cattle (Topolko and Benić, 1997). Cows with subclinical mastitis produce $20 \%$ less milk which at the same time may threaten human health. Studies performed in the USA during year 2001, which comprised more than 6000 herds of dairy cows, established subclinical mastitis in $45 \%$ of lower productive and in $26 \%$ of high productive herds (Ruegg, 2003). Subclinical form of mastitis may quickly transform into clinical form of disease. Depending on the causative agent, subclinical mastitis occurs in herds 2-20 times more frequently than its clinical form. Thus, early diagnosis of subclinical mastitis is very important for prevention and spreading of the disease (Bačić, 2009).

Clinical mastitis is easier to diagnose due to the presence of visible clinical signs. In some cases, it is possible to establish correct diagnosis without performing diagnostic tests (Russell, 2011). Considering the duration of the disease, clinical mastitis may be peracute, acute, subacute or chronic disease. The affected udder may not be visibly changed. However, the consistency of milk is changed with visible patches and fibrous structures made of clusters of desquamated epithelium, leukocytes and proteins. Clinical mastitis could be divided into mild, moderate and severe form according to manifestation of its symptoms (Bačić, 2009). In case of mild form, only changes in milk appearance occur. The moderate form is characterized by mild changes in general health status of an animal such as fever, increased respiratory rate and increased heart frequency. The severe form of mastitis is characterized by significant systemic changes accompanied by local changes in the mammary gland (Beecher et al., 2011). External clinical signs of mastitis are redness, edema, warmness and soreness of the udder (Tyler and Cullor, 2002).

\section{Causative agents of mastitis}

The most commonly recognized causative agents of mastitis are bacteria followed by mycoplasmas, yeasts, molds, fungi and even algae (Bačić, 2009; Beecher et al., 2011). The causative agents of mastitis vary according to different management conditions in different countries. The most significant bacteria causing mastitis are: S. aureus, Streptococcus agalactiae, E. coli, Corynebacterium bovis and 
Mycoplasma bovis. The severity of diseases depends on microorganism species, infective dose, host resistance and rearing conditions. The causative agents of mastitis are divided into contagious and environmental pathogens. The contagious agents of mastitis are: S. aureus, S. agalactiae, M. bovis and C. bovis. The pathogens are usually located on the udder skin, in ductus pappilaris and on mucosal surfaces of the infected udder. The spreading of infection is supported by milking when the pathogen is transferred from affected to non-affected quarter of the udder (Russell, 2011). The most common environmental pathogens in mastitis are coliform bacteria and S. uberis, S. dysgalactiae and S. bovis. These microorganisms could be found in the cow's environment, feces and on the cow's skin as well. The infection occurs following transfer of bacteria from the environment to the udder during milking usually by using contaminated equipment (Bačić, 2009; Maćešić et al., 2012).

\section{Pathogenesis of mastitis}

The first barrier of the mammary gland against microorganism invasion is stenosis of ductus pappilaris. Inside ductus pappilaris there is keratin which promotes the attachment of ductus walls. Besides, keratin binds bacteria and prevents their penetration into the milk cistern (Russell, 2011). When such a natural barrier is damaged, pathogens can easily enter into ductus pappilaris of the udder and cause the infection. Besides this anatomical barrier, mammary gland is protected from bacterial invasion by diverse defence mechanisms which include innate and acquired or specific immunity (Benoit et al., 2008). The cells that participate in defence of the mammary gland from pathogen invasions include: neutrophils, macrophages, lymphocytes and epithelial cells (Riollet et al., 2000). Inflammatory response during mastitis is marked by the increased blood flow in infected tissue, increased vascular permeability, leukocyte migration from blood vessels into interstitial space and accumulation of leukocytes at the site of trauma (Tkalčević and Hrvačić, 2011). Bacteria release toxins which activate leukocytes and epithelial cells in the mammary gland to release cytokines which attract numerous polymorphonuclear leukocytes (PMN) functioning as phagocytic cells at the site of infection (Paape et al., 2003). PMN such as neutrophils and macrophages are the first cells infiltrating the site of trauma (Wellnitz et al., 2012).
Chemotaxis signals of chemokines, cytokines, metalloproteinase matrix and bacterial products stimulate accumulation of neutrophils and macrophages at the site of infection. Inflammatory mediators, such as bacterial lipopolysaccharide, TNF- $\alpha$ and platelet activating factor (PAF), significantly stimulate response of neutrophils to chemotaxis (Chinen et al., 2006). Following diapedesis, neutrophils become macrophages and initiate their main function i.e. phagocytosis and pathogen destruction which is associated with release of numerous inflammatory mediators (Burvenich, 2004). During phagocytosis, macrophages also release the substances which may damage mucosal surface of the mammary gland. Damaged tissue will be replaced with the fibrous tissue with a consequence of the decreased number of secretory cells. Also, PMN possess membrane receptors enabling their migration through endothelium. Selectins, the surface molecules of leukocytes, platelets and endothelial cells are responsible for initiation of adherence of leukocytes to endothelial cells. When leukocytes occurred in milk they are surrounding by fat droplets and casein, and simultaneously opsonins are released in order to attract more leukocytes from blood into milk (Pappe et al., 2003). Neutrophils and macrophages release enzymes and inflammatory mediators and reactive oxygen species (ROS) by which they promote elimination of bacteria, but also cause damages of surrounding tissue (Pham, 2006). Mastocytes, platelets and basophils produce vasoactive amines such as serotonin and histamine (Kovač, 2002).

During inflammatory response, numerous proinflammantory and anti-inflammatory mediators are released and the balance between them determines intensity and outcome of the disease. In case of equilibrium between these two groups of mediators, the inflammatory response in the mammary gland will terminate and the animal will completely recover considering that as a mild form of inflammation. However, if the balance is not established, the inflammatory mediators may cause inflammatory response with possible clinical signs of mastitis.

During inflammatory response, neutrophils, macrophages and other inflammatory cells produce ROS for killing pathogens. As a consequence of ROS accumulation, oxidative stress could develop. Excessive amount of ROS and other products of oxidative stress, such as lipid hydroperoxides, could addition- 
ally contribute to cell and tissue destruction (Ryman et al., 2015). Additionally, increased production of ROS in milk impairs also its organoleptic properties and directly reduces milk quality (Lykkesfeldt and Svendsen, 2007).

\section{Oxidative stress}

Oxidative stress is defined as imbalance between production of ROS and capability of an organism to immediately remove reactive by-products or repair resulting damages (Mandelker, 2004). Oxidative stress could be a consequence of one out of three factors: increased production of ROS, decreased antioxidant protection and inability of repairing induced damages. Due to the fact that ROS production is a part of physiological processes of reproductive system, any shift from balance between production and elimination of ROS may have influence on reproductive function (Agarwal et al., 2006). Failure in metabolic adaptation and negative energy balance (NEB) during transition period represent a key point in oxidative stress development (Turk et al., 2008a and 2011).

Oxidative phosphorylation, the key process of energy metabolism of aerobic organisms, is crucial for complex mechanism of oxidative stress. This is a process in which the energy obtained by electron transport in mitochondria by enzymatic complex $\mathrm{NADH}$ dehydrogenases transforms energy rich phosphate bonds into ATP molecules. The oxygen serves as a final acceptor of electrons of distal part of enzymatic complex, i.e. cytochrome c oxidase which catalyse the reduction of oxygen into water (Fulton, 1997). During the latter process, partly reduced and highly reactive oxygen metabolites termed ROS are created (Thannickal and Fanburg, 2000).

\section{Reactive oxygen species (ROS)}

Oxygen metabolites or ROS may be classified into two groups: free oxygen radicals and non-radical species (Halliwell and Gutteridge, 1987). Free oxygen radicals are defined as chemical species with one or two unpaired electrons in external orbitals (Shackelford et al., 2000). Non-radical oxygen compounds do not have unpaired electrons, but in spite of that they are unstable compounds which may react with free radicals producing new, and even more reactive, free radicals. ROS include: superoxide anion $\left(\cdot \mathrm{O}_{2}^{-}\right)$, hydroxyl radical $(\cdot \mathrm{OH})$, hydrogen peroxide $\left(\mathrm{H}_{2} \mathrm{O}_{2}\right)$, ozone $\left(\mathrm{O}_{3}\right)$ and singlet oxygen $\left({ }^{1} \mathrm{O}_{2}\right)$, (Kumar et al., 2011). Free oxygen radicals are hydroxyl radical $(\cdot \mathrm{OH})$ and superoxide anion $\left(\cdot \mathrm{O}_{2}^{-}\right)$, while hydrogen peroxide $\left(\mathrm{H}_{2} \mathrm{O}_{2}\right)$ belongs to non-radical species (Halliwell et al., 1992). In order to attain stability, free radicals acquire electrons from stable macromolecules (lipids, proteins, DNA) resulting in damages of cell and tissue structure and function (Nordberg and Arnér, 2001; Žarković et al., 2002).

The ROS are products of normal aerobic metabolism, however they may also be produced by influence of external factors (UV and ionizing radiation, chemotherapeutics, environmental toxins, inflammation). During phagocytosis, ROS are also produced in the process of oxidative phosphorylation (Lee and Wei, 2000). Majority of them are released by any biochemical redox reaction which includes oxygen (Devasagayam et al., 2004). Depending of concentration, ROS may be useful or harmful to cells and tissues (Mittler, 2002; Turk et al., 2008a). If the capability of an organism to eliminate ROS by means of antioxidants fails, ROS damages proteins, lipids and DNA and induce oxidative stress (Sanz, 2016). At physiological levels, ROS participate in synthesis of biologically important molecules, regulation of cell growth and cell signalling (Nordberg and Arnér, 2001). Additionally, they have an important role in the regulation of reproductive processes such as folliculogenesis, oocyte maturation, embryogenesis and others (Agarwal et al., 2008). ROS production increases during infection, body activity, exposure to contamination, UV and ionizing radiation. ROS may act directly and indirectly on the organism.

\section{Superoxide anion $\left(\cdot \mathrm{O}_{2}^{-}\right)$}

Superoxide anion $\left(\cdot \mathrm{O}_{2}^{-}\right)$is a very reactive compound generated by the addition of a single electron to oxygen $\left(\mathrm{O}_{2}\right)$ during electron transport chain in mitochondria (Valko et al., 2007). It may immediately interact with other molecules and induce occurrence of new free radicals, particularly hydroxyl 
radical $(\cdot \mathrm{OH})$ (Figure 1$)$. It is considered that this compound is precursor of hydrogen peroxide. Superoxide dismutase (SOD) protects cells from damaging effect of superoxide anion by its conversion to $\mathrm{H}_{2} \mathrm{O}_{2}$ (Bull et al., 1991; Laukkanen, 2016). Five different isoforms of SOD enzymes are well known, out of which 3 are structurally characterized. In mammals, there are 3 isoforms of SOD: SOD1 which is located in cytoplasm, SOD2 located in mitochondria and SOD3 located in extracellular spaces.

\section{Hydrogen peroxide $\left(\mathrm{H}_{2} \mathrm{O}_{2}\right)$}

Hydrogen peroxide $\left(\mathrm{H}_{2} \mathrm{O}_{2}\right)$ is a compound which is assigned into non-radical oxygen compounds (Mittler, 2002). It is produced in mitochondria during the process of oxidative phosphorylation. It has an important role in intracellular signalling and cellular reactions and may pass through biological membranes (Al-Gubory et al., 2010). In spite the fact that hydrogen peroxide does not possess free electrons, it could act as oxidant in the presence of transition metals, bivalent iron $\left(\mathrm{Fe}^{2+}\right)$ and bivalent copper $\left(\mathrm{Cu}^{2+}\right)$ producing more reactive hydroxyl radical (Sontakke, 2014). This reaction is termed Haber-Weis reaction (Figure 2) (Kehrer, 2000).

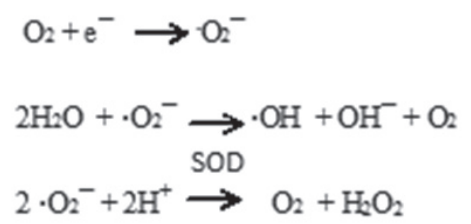

Figure 1. Oxygen reduction and reactions of ROS generation

$$
\begin{aligned}
& \mathrm{Fe}^{3+} / \mathrm{Cu}^{2+}+\cdot \mathrm{O}_{2}^{-} \longrightarrow \mathrm{Fe}^{2+}+\mathrm{O}_{2} \\
& \mathrm{Fe}^{2+} / \mathrm{Cu}^{2+}+\mathrm{H}_{2} \mathrm{O}_{2} \longrightarrow \cdot \mathrm{OH}+\mathrm{OH}^{-}+\mathrm{Fe}^{3+} \text { (Fenton reaction) } \\
& \mathrm{O}_{2}^{-}+\mathrm{H}_{2} \mathrm{O}_{2} \stackrel{\mathrm{Fe}^{3+} / \mathrm{Cu}^{2+}}{\longrightarrow} \cdot \mathrm{OH}+\mathrm{OH}^{-}+\mathrm{O}_{2} \quad \text { The net reaction (Haber- Weis reaction) }
\end{aligned}
$$

Figure 2. Reactions with hydrogen peroxide in the presence of transition metals
Hydroxyl radical $(\cdot \mathrm{OH})$

Hydroxyl radical $(\cdot \mathrm{OH})$ is produced following reaction of hydrogen peroxide with metal ions such as $\mathrm{Fe}^{2+}$ and $\mathrm{Cu}^{+}$(Hayyan et al., 2016). Sometimes it could be produced as a by-product of the immune activity. Hydroxyl radical may damage almost all kinds of macromolecules: carbohydrates, nucleic acids, lipids and proteins. In contrary to superoxide which could be eliminated by SOD, hydroxyl radical could not be eliminated by enzymatic reactions. Mechanisms for its elimination include: endogenous antioxidants such as melatonin and glutathione and nutritive antioxidants such as mannitol and vitamin $\mathrm{E}$ (Reiter et al., 1995).

\section{Antioxidantive system}

Each mammalian organism possesses a natural antioxidantive system in order to protect itself from damaging effects of ROS (Beattie, 2006). The antioxidantive system does not eliminate oxidants in total but rather maintains their optimal levels (Rhee, 2006). Antioxidant substance is defined as an agent which decelerates or totally reduces oxidation or even eliminate oxidative damage.

The antioxidants are assigned into two groups depending on their water solubility (hydrophilic) or lipid solubility (lipophilic). Generally, water soluble antioxidants react with oxidants in cytosol and blood plasma whereas those soluble in lipids protect cell membrane from lipid peroxidation (Sies, 1997). They may be synthesized in vivo or derived from a diet (Sordillo and Aitken, 2009), and these are macromolecules which may bind metal ions and antioxidative enzymes. The antioxidants could be also classified either as enzymatic or nonenzymatic antioxidants or as preventive or chain-breaking antioxidants (Miller et al., 1993; Agarwal et al., 2006). 
Preventive system includes metal-binding macromolecules and antioxidant enzymes. The macromolecules which bind metal ions are transferrin, ceruloplasmin and albumin. Since the metal ions act as catalysts in ROS producing reactions, this kind of antioxidants may eliminate them from extracellular fluid. Antioxidant enzymes, SOD, catalase and glutathione peroxidase act inside the cell and remove - $\mathrm{O}_{2}{ }^{-}$and $\mathrm{H}_{2} \mathrm{O}_{2}$ before they become available for Fenton reaction to produce more reactive $\cdot \mathrm{OH}$ radical (Halliwell and Gutteridge, 1987). In spite of the activity of preventive enzymes, some ROS may remain and cause deleterious effect on macromolecules. In this situation, there are some other antioxidant enzymes that are chain-breaking and inhibit oxidative damage of macromolecules such as paraoxonase-1 (PON1), platelet-activating factor acetylhydrolase (PAF-AH) and lecitin:cholesterol acyltransferase (LCAT) that prevent and retard oxidative modification of lipoproteins (Parthasarathy et al., 1990; Turk et al., 2005, 2008a,b). Chainbreaking antioxidants act after the initiation of chain reaction with ROS. They comprise antioxidant vitamins, minerals, enzymes and other substances of endogenous or exogenous origin such as vitamin C, vitamin $\mathrm{E}$, selenium, zinc, ubiquinone, taurine, hypotaurine, glutathione, beta carotene and carotene (Miller et al., 1993). Vitamin A and other carotenoids are present in high concentrations in animal feed. Vitamin C is natural product of animal cells (Clarkson and Thompson, 2000). Vitamin E or tocopherol exhibits strong antioxidative effects and together with dietary selenium prevents oxidation of polyunsaturated fatty acids, reacts with free radicals and protects unsaturated membrane lipids from oxidation. Significant attention has been given to the regulation of antioxidant intake by food (microelements, vitamins) and in that way, good control of incidence of mastitis is attained (Bernabucci et al., 2005). During lactation, milk production subsequently exhausted dairy cows. Thus, it is necessary, to pay attention on diet composition during dry period, particularly proteins, minerals and vitamins, in order to achieve optimal body condition and certain energy reserves. In cases when cow has suboptimal or over optimal body condition at parturition, milk production is reduced and animal could become more susceptible to infections (Sontakke, 2014; Folnožić at al., 2015).

\section{Concluding comments}

In the pathogenesis of mastitis a key role plays the innate immune response which is the first line of defence following invasion of the mammary gland by pathogens. After the invasion of the mammary gland by pathogens, macrophages are accumulated at the site of infection releasing a number of proinflammantory and anti-inflammatory mediators such as: cytokines, chemokines, lipid mediators, proteolytic enzymes and other molecules that may act locally but also systemically producing a local and/or systemic inflammatory responses. During inflammation, particularly in the process of phagocytosis, ROS are produced acting on pathogen destruction which may lead to oxidative stress. Metabolic load occurred during peripartal period, from dry period to early lactation, is an additional potential source of oxidants and ROS in dairy cows and could be predisposing factor for development of oxidative stress and inflammatory response. An excessive ROS production induces oxidative changes of cellular and extracellular macromolecules and by that inhibits protein function, induces lipid peroxidation and in reaction with DNA may lead to mutations and cell dead. Antioxidantive status of cows in peripartal period is thus impaired due to increased antioxidant consumption. The relationship between inflammatory response and oxidative stress during mastitis indicates their important roles in the pathogenesis of mastitis. In order to prevent oxidative stress and moderate inflammatory response as well as to improve immune status of dairy cows it is very important that their nutritive needs are well balanced by special meal composition with appropriate ratio of minerals, vitamins and antioxidants which could prevent and/or moderate mastitis and the other diseases occurring in dairy industry.

\section{Acknowledgement}

This work was supported by a grant from the Croatian Scientific Foundation, Croatia (Project no. IP-2014-09-6601, ModZeCow). The principal investigator of the project is Marko Samardžija, DVM, PhD, Full Professor, Faculty of Veterinary Medicine University of Zagreb, Croatia. 


\section{Uloga oksidacijskog stresa i upalnog odgovora u patogenezi mastitisa u mliječnih krava}

\section{Sažetak}

Mastitis je jedna od najčešćih bolesti mliječnih goveda u cijelom svijetu, jer uzrokuje najveće gubitke u mliječnom gospodarstvu. Ima značajan utjecaj sa stanovišta javnog zdravstva, prerade mlijeka i dobrobiti životinja. Ekonomski gubitci se očituju kroz: smanjenu proizvodnju mlijeka, velike troškove liječenja, prijevremeno izlučivanje životinja, vrijednost odbačenog mlijeka te smanjenu plodnost. U patogenezi mastitisa ključnu ulogu ima urođeni imunosni odgovor koji je prva linija obrane nakon što patogen prodre u mliječnu žlijezdu. Upala je standardna reakcija organizma na ozljedu bilo kakvog fizičkog, kemijskog ili biološkog uzroka, no prije svega to je vitalni zaštitni mehanizam, koji uključuje proizvodnju reaktivnih kisikovih spojeva (ROS), fagocitne mehanizme, izlučivanje protumikrobnih tvari, stvaranje ožiljkastog tkiva i neovaskularizaciju te promjene tkivne strukture zahvaćenog organa ili tjelesnog prostora. Metaboličko opterećenje nastalo prilikom prelaska iz perioda zasušenja u period rane laktacije je dodatno potencijalni izvor oksidansa i ROS-a u mliječnih krava i pogodovni čimbenik za nastanak oksidacijskog stresa i upalnog odgovora. Oksidacijski stres definiran je kao pomak ravnoteže u staničnim oksido-redukcijskim reakcijama prema oksidaciji, odnosno to je stanje prekomjernog stvaranja slobodnih radikala kisika i ROS pri čemu se nadilazi mogućnost njihova uklanjanja. Antioksidacijski status krava u peripartalnom periodu je stoga oslabljen $\mathrm{i}$ posljedično oksidacijski stres i upalni odgovor mogu predisponirati osjetljivosti krave za intramamarne infekcije (IMI) i mastitis. Povezanost između upalnog odgovora i oksidacijskog stresa tijekom IMI i mastitisa ukazuje na njihovu važnu ulogu u patogenezi bolesti mliječne žlijezde te stoga bolje razumijevanje takvog sinergizma može doprinijeti razvoju novih pristupa u prevenciji i liječenju IMI i mastitisa.

Ključne riječi: oksidacijski stres, upalni odgovor, mastitis, peripartum, krava

\section{References}

1. Agarwal, A., Gupta, S., Sikka S. (2006): The role of free radicals and antioxidans in reproduction. Current Opinion in Obstetrics and Gynecology 18, 325-332. https://doi.org/10.1097/01.gco.0000193003.58158.4e

2. Agarwal, A., Gupta, S., Sekhon, I., Shah, R. (2008): Redox considerations in female reproductive functions and assisted reproduction: from molecular mechanisms to health implications. Antioxidants \& Redox Signaling 10, 1375-1403. https://doi.org/10.1089/ars.2007.1964

3. Al-Gubory, K.H., Fowler, P.A., Garrel, C. (2010): The roles of cellular reactive oxygen species, oxidative stress and antioxidants in pregnancy outcomes. The International Journal of Biochemistry \& Cell Biology 42, 1634-1650. https://doi.org/10.1016/j.biocel.2010.06.001

4. Bačić, G. (2009): Dijagnostika i liječenje mastitisa u goveda. (ur. G. Bačić, S. Vince, N. Maćešić). Veterinarski fakultet Sveučilišta u Zagrebu. (in Croatian).

5. Barbano, D.M., Verdi, R.J., Rasmussen R. (1987): Influence of milk somatic cell count on cheese manufacturing and cheese yield. Proceedings of $24^{\text {th }}$ Annual Marschall Italian \& Specialty Cheese Seminars, Madison.

6. Bassols, A., Turk, R., Roncada, P. (2014): A proteomics perspective: from animal welfare to food safety. Current Protein and Peptide Science 15, 156-168. https://doi.org/10.2174/1389203715666140221125958

7. Beattie, S. D. (2006): Bioenergetics and oxidative metabolism. In: Devlin, T. M. ed., Textbook of Biochemistry with Clinical Correlations. $6^{\text {th }}$ ed. New York, NY: Wiley-Liss, pp. 978-989.

8. Beecher, C., McCarthy, T.V., Giblin, L. (2011): Mastitis and bovine milk production. In: Dairy cows, Nutrition, fertility and milk production, Nova Science Publishers, Inc. Pp. 1-56.

9. Benić, M. (2011): Mastitisi u krava. Mljekarski list 3, 1-12.

10. Benoit, M., Desnues, B., Mege, J.L. (2008): Macrophage polarization in bacterial infections. Journal of Immunology 181, 3733-3739. https://doi.org/10.4049/jimmunol.181.6.3733

11. Bernabucci, U., Ronchi, B., Lacetera, N., Nardone A. (2005): Influence of body condition score on relationships between metabolic status and oxidative stress in periparturient dairy cows. Journal of Dairy Science 88, 2017-2026. https://doi.org/10.3168/jds.S0022-0302(05)72878-2

12. Bull, C., Niederhoffer, E.C., Yoshida T. (1991): Kineticstudies of Superoxide dismutase-properties of the manganese-containing protein from thermos-thermophilus. Journal of the American Chemical Society 113, 4069-4076. https://doi.org/10.1021/ja00011a003

13. Burvenich, C., Monfardini, E., Mehrzad, J., Capuco, A.V., Paape, M.J. (2004): Role of neutrophil polymorphonuclear leukocytes during bovine coliform mastitis: physiology or pathology? Verhandelingen - Koninklijke Academie Voor Geneeskunde Van Belgie 66, 97-150. 
14. Chinen, T., Kobayashi, T., Ogata, H., Takaesu, Takaki, G., H., Hashimoto, M., Yagita, H., Nawata, H., Yoshimura, A. (2006): Suppressor of cytokine signaling-l regulates inflammatory bowel disease in which Both IFN $\gamma$ and IL-4 are involved. Gastroenterology 130, 373-388. https://doi.org/10.1053/j.gastro.2005.10.051

15. Clarkson, P.M., Thompson, H.S. (2000): Antioxidants: what role did they play in physical Activity and health. The American Journal of Clinical Nutrition 72, 637-646.

16. Cvetnić, L., Samardžija, M., Habrun, B., Kompes, G., Benić, M. (2016): Microbiological monitoring of mastitis pathogens in the control of udder health in dairy cows. Slovenian Veterinary Research 53, 131-140.

17. Deb, R., Kumar, A., Chakraborty, S., Kumar, S. (2013): Trends in diagnosis and control of bovine mastitis. $\mathrm{Pa}$ kistan Journal of Biological Sciences 16, 1653-1661. https://doi.org/10.3923/pjbs.2013.1653.1661

18. Devasagayam, T.,J.C. Tilak, J.C., Boloor, K.K., Sane Ketaki, S., Ghaskadbi Saroj, S., Lele, R.D. (2004): Free radicals and antioxidants in human health: Current status and future prospects. Journal of the Association of Physicians of India (JAPI) 52, 794-804.

19. Djuricic, D., Samardzija, M., Grizelj, J., Dobranic, T. (2014): Effet du traitement intramammaire des mammites subcliniques pendant la lactation en élevages bovins laitiers au nord-ouest de la Croatie. Annales de Médecine Vétérinaire 159, 121-125.

20. Dobranić, V., Njari, B., Samardžija, M., Selec, A., Mioković, B., Medvid, V. (2007): Saisonbedingte Änderungen der mikrobiologischen Milchflora unter besonderem Berücksichtigung auf von Pilzen. Tierärztliche Umschau 62, 300-309.

21. Folnožić, I., Turk, R., Đuričić, D., Vince, S., Pleadin, J., Flegar-Meštrić, Z., Valpotić, H., Dobranić, T., Gračner, D., Samardžija, M. (2015): Infuence of body condition on serum metabolic indicators of lipid mobilisation and oxidative stress in dairy cows during the transition period. Reproduction in Domestic Animals 50, 910-917. https://doi.org/10.1111/rda.12608

22. Fulton, D., McGiff, J.C., Wolin, M.S. (1997): Evidence against cytochrome $\mathrm{P} 450$ - derived reactive oxygen species as the mediator of the nitric oxide-independent vasodilator effect of bradykinin in the perfused heart of the rat. Journal of Pharmacology and Experimental Therapeutics 280, 702-709.

23. Gračner, D., Bedrica, Lj., Cergolj, M., Harapin, I., Samardžija, M., Gregurić Gračner, G., Žubčić, D., Rešetić, J., Fury, M. (2006): Haptoglobinspiegel in Blut und Milch von Kühen mit einer Staphylokokkenmastitis. Tierärtzliche Umschau 61, 636-641.

24. Halliwell, B., Gutteridge, J.M. (1987): Oxygen toxicity, oxygen radicals, transition metals and disease. Biochemical Journal 219, 1-14. https://doi.org/10.1042/bj2190001

25. Halliwell, B., Gutteridge, J.E., Cross, C.E. (1992): Free radicals, antioxidants, and human disease: where are we now? Journal of Laboratory and Clinical Medicine 119, 598-620.
26. Hayyan, M., Hashim, M.A., AlNashef, I.M. (2016): Superoxide ion, generation and chemical implications. Chemical Reviews 116, 3029-3085. https://doi.org/10.1021/acs.chemrev.5b00407

27. Kehrer, J.P. (2000): The Haber-Weiss reaction and mechanisms of toxicity. Toxicology 149, 43-50. https://doi.org/10.1016/S0300-483X(00)00231-6

28. Kovač, Z. (2002): Upale. U: Patofiziologija. (Ur. Gamulin, S., M. Marušić, Z. Kovač). Medicinska naklada, Zagreb. str. 471-499.

29. Kumar, A., Dwivedi, H.P., Swarup, D. (2011): Oxidative Stress in Periparturient Metabolic Disorders. In: Production Diseases of Dairy Animals, SSPH, pp. 19-27.

30. Laukkanen, M.O. (2016): Extracellular superoxide dismutase: growth promoter or tumor suppressor? Oxidative Medicine and Cellular Longevity Vol. 2016, 9 pages, https://doi.org/10.1155/2016/3612589.

31. Lee, H.C., Wei, Y.H. (2000): Mitochondrial role in life and death of the cell. Journal of Biomedical Science 7, 2-15. https://doi.org/10.1007/BF02255913

32. Lykkesfeldt, J., Svedsen, O. (2007): Oxidants and antioxidants in disease: Oxidative stress in farm animals. The Veterinary Journal 173, 502-511. https://doi.org/10.1016/j.tvj1.2006.06.005

33. Maćešić, N., Bačić, G., Božičević, K., Benić, M., Karadjole, T., Prvanović Babić, N., Lojkić, M., Efendić, M., Bačić, I., Pavlak, M. (2016): Assessment of the Zagreb mastitis test in diagnosis of mastitis in dairy cattle. Veterinarski arhiv 86, 475-485.

34. Maćešić, N., Karadjole, T., Bačić, G., Benić, M., Karadjole, M., Vince, S., Lipar, M., Cergolj, M. (2012): Aetiology and prevalence of bovine intramammary infection at drying off. Veterinarski arhiv 82, 125-131.

35. Mandelker, L. (2004): The natural activities of cells, the role of reactive oxygen species, and their relation to antioxidants, neutraceuticals, botanicals and other biological therapies. Veterinary Clinics of North America: Small Animal Practice 34, 39-66. https://doi.org/10.1016/j.cvsm.2003.09.014

36. Mattila, T. (1986): Diagnostic problems in bovine mastitis. Academic disertation, College of Veterinary Medicine, Helsinki.

37. Miller, J.K., Brzezinska-Slebodzinska, E., Madsen, F.C. (1993): Oxidative stress, antioxidants, and animal function. Journal of Dairy Science 76, 2812-2823. https://doi.org/10.3168/jds.S0022-0302(93)77620-1

38. Mittler, R. (2002): Oxidative stress, antioxidants and stress tolerance. Trends in Plant Science 7, 405-410. https://doi.org/10.1016/S1360-1385(02)02312-9

39. Nordberg, J., Arnér, E.S.J. (2001): Reactive oxygen species, antioxidants, and the mammalian thioredoxin system. Free Radical Biology \& Medicine 31, 1287-1312. https://doi.org/10.1016/S0891-5849(01)00724-9

40. Paape, M.J., Bannermann, D.D., Zhao, X., Lee, J.W. (2003): The bovine neutrophil: Structure and function in blood and milk. Veterinary Research 34, 597-627. https://doi.org/10.1051/vetres:2003024 
41. Parthasarathy, S., Barnett, J., Fong, L.G. (1990): High-density lipoprotein inhibits the oxidative modification of low-density lipoprotein. Biochimica et Biophysica Acta 1044, 275-283. https://doi.org/10.1016/0005-2760(90)90314-N

42. Pham, C.T.N. (2006): Neutrophil serine proteases: specific regulators of inflammation. Nature Reviews Immunology 6, 541-550. https://doi.org/10.1038/nril841

43. Radostitis, O.M., Gay, C.C., Blood, D.C., Hinchcliff, K.W. (2000): Mastitis. In: Veterinary medicine. A textbook of the diseases of cattle, sheep, pigs, goats and horses $9^{\text {th }}$ ed., W. B. Saunders Company. Philadelphia, London, New York, St. Louis, Toronto, pp. 603-700.

44. Reiter, R.J., Melchiorri, D., Sewerynek, E., Poeggeler, B., Barlow-Walden, L., Chuang, J., Ortiz, G.G., Acuňa-Castroviejo, D. (1995): A review of the evidence supporting melatonin's role as an antioxidant. Journal of Pineal Research 18, 1-11. https://doi.org/10.1111/j.1600-079X.1995.tb00133.x

45. Rhee, S.G. (2006): $\mathrm{H}_{2} \mathrm{O}_{2}$, a necessary evil for cell signalling. Science 312, 1882-1883. https://doi.org/10.1126/science.1130481

46. Riollet, C., Rainard, P., Poutrel, B. (2000): Cells and cytokines in inflammatory secretions of bovine mammary gland. Advances in Experimental Medicine and Biology 480, 247-258. https://doi.org/10.1007/0-306-46832-8_30

47. Roncada, P., Piras, C., Soggiu, A., Turk, R., Urbani, A., Bonizzi, L. (2012): Farm animal milk proteomics. Journal of Proteomics 75, 4259-4274. https://doi.org/10.1016/j.jprot.2012.05.028

48. Ruegg Pamela, L. (2003): Investigation of mastitis problems on farms. Veterinary Clinics of North America: Food Animal Practice 19, 47-73. https://doi.org/10.1016/S0749-0720(02)00078-6

49. Russell, R.J. (2011): Bovine mastitis. In: Production diseases of dairy animals. Satish serial publishing house, pp. 351-390.

50. Ryman, V.E., Packiriswamy, N., Sordillo L.M. (2015): Role of endothelial cells in bovine mammary gland health and disease. Animal Health Research Reviews 16, 135-149. https://doi.org/10.1017/S1466252315000158

51. Salman, S., Khol-Parisini, A., Schafft, H., LahrssenWiederholt, M., Hulan, H.W., Dinse, D., Zentek, J. (2009): The role of dietary selenium in bovine mammary gland health and immune function. Animal Health Research Reviews 10, 21-34. https://doi.org/10.1017/S1466252308001588

52. Sanz, A. (2016): Mitochondrial reactive oxygen species: Do they extend or shorten animal lifespan? Biochimica et Biophysica Acta 1857, 1116-1126. https://doi.org/10.1016/j.bbabio.2016.03.018

53. Sies, H. (1997): Oxidative stress: oxidants and antioxidants. Experimental Physiology 82, 291-295. https://doi.org/10.1113/expphysiol.1997.sp004024
54. Shackelford, R.E., Kaufmann, W.K., Paules R.S. (2000): Oxidative stress and cell cycle checkpoint function. Free Radical Biology \& Medicine 28, 1387-1404. https://doi.org/10.1016/S0891-5849(00)00224-0

55. Sontakke, U., Bhakat, M., Mondal, G. (2014): Oxidative Stress and Fertility in Dairy Animals. Dairy Cattle Nutrition Division, National Dairy Research Institute, Karnal, India, Dairy cattle.

56. Sordillo, L.M., Aitken, S.L. (2009): Impact of oxidative stress on the health and immune function of dairy cattle. Veterinary Immunology and Immunopathology 128, 104-109. https://doi.org/10.1016/j.vetimm.2008.10.305

57. Thannickal, V.J., Fanburg, B.L. (2000): Reactive oxygen species in cell signalling. The American Journal of Physiology - Lung Cellular and Molecular Physiology 279, 1005-1028.

58. Tkalčević, I.V., Hrvačić, B. (2011): Upalna reakcija kao temeljni homeostatski mehanizam. Veterinarska stanica 42, 347-360.

59. Topolko, S., Benić, M. (1997): Aktualni problemi i epizootiološko stanje supkliničkih mastitisa u minifarmskoj proizvodnji mlijeka. Praxis veterinaria 45, 69-76.

60. Turk, R., Juretić, D., Gereš, D., Turk, N., Rekić, B., Simeon-Rudolf, V., Robić, M., Svetina, A. (2005): Serum paraoxonase activity in dairy cows during pregnancy. Research in Veterinary Science 79, 15-18. https://doi.org/10.1016/j.rvsc.2004.09.010

61. Turk, R., Juretić, D., Gereš, D., Svetina, A., Turk, N., Flegar-Meštrić, Z. (2008a): Influence of oxidative stress and metabolic adaptation on PON 1 activity and MDA level in transition dairy cows. Animal Reproduction Science 108, 98-106. https://doi.org/10.1016/j.anireprosci.2007.07.012

62. Turk, R., Juretić, D., Gereš, D., Bačić, G., Milešević, M., Flegar-Meštrić, Z., Turk, N., Svetina, A. (2008b): Bovine platelet-activating factor acetylhydrolase (PAF-AH) activity related to fertility. Animal Reproduction Science 105, 344-353. https://doi.org/10.1016/j.anireprosci.2007.03.016

63. Turk, R., Samardžija, M., Bačić, G. (2011): Oxidative stress and reproductive disorders in dairy cows. In: Dairy cows: Nutrition, Fertility and Milk Production, Nova Science Publishers, Inc., pp. 57-98.

64. Turk, R., Piras, C., Kovačić, M., Samardžija, M., Ahmed, H., Da Canio, M., Urbani, A., Flegar Meštrić, Z. Soggiu, A., Bonizzi, L., Roncada, P. (2012): Proteomics of inflammatory and oxidative stress response in cows with subclinical and clinical mastitis. Journal of Proteomics 75, 4412-4428. https://doi.org/10.1016/j.jprot.2012.05.021

65. Turk, R, Podpečan, O., Mrkun, J., Kosec, M., Flegar-Meštrić, Z., Perkov, S., Starič, J., Robić, M., Belić, M., Zrimšek, P. (2013): Lipid mobilisation and oxidative stress as metabolic adaptation processes in dairy heifers during transition period. Animal Reproduction Science 141, 109-115. https://doi.org/10.1016/j.anireprosci.2013.07.014 
66. Turk, R, Podpečan, O., Mrkun, M., Flegar-Meštrić, Z., Perkov, S., Zrimšek, P. (2015): The effect of seasonal thermal stress on lipid mobilisation, antioxidant status and reproductive performance in dairy cows. Reproduction in Domestic Animals 50, 595-603. https://doi.org/10.1111/rda.12534

67. Turk, R., Folnožić, I., Đuričić, D., Vince, S., FlegarMeštrić, Z., Dobranić, T., Valpotić, H., Samardžija, M. (2016): Relationship between paraoxonase-1 activity and lipid mobilisation in transition dairy cows. Veterinarski arhiv 86, 601-612.

68. Tyler, J.W., Cullor, J.S. (2002): Mammary Gland Health and Disorders. In: Large Animal Internal Medicine (B. P. Smith, ed.), Mosby, St. Louis, London, Philadelphia, Sydney, Toronto, pp. 1019-1038.
69. Valko, M., Liebfritz, D. Moncol, J., Telser, J. (2007): Free radicals and antioxidants in normal physiological functions and human disease. The International Journal of Biochemistry \& Cell Biology 39, 44-84. https://doi.org/10.1016/j.biocel.2006.07.001

70. Valpotić, I. (2002): Imunost i stres: Koncepcija o međudjelovanju. Hrvatski veterinarski vjesnik 25, 49-65.

71. Wellnitz, O., Bruckmaier, R.M. (2012): The innate immune response of the bovine mammary gland to bacterial infection. The Veteterinary Journal 192, 148-152. https://doi.org/10.1016/j.tvj1.2011.09.013

72. Žarković, N., Borović, S., Stipančić, I., Blaži, M. P., Lončarić, I., Čipak, A., Jurić, G., Vuković, T., Wonisch, W., Waeg, G., Žarković, K. (2002): Fiziološke i patološke značajke lipidne peroksidacije. U: Oksidativni stres i djelotvornost antioksidanta, str. 10-29. 